Etnográfica

Revista do Centro em Rede de Investigação em

Antropologia

vol. 12 (1) | 2008

Vol. $12(1)$

\title{
Os nomes de família em Portugal: uma breve perspectiva histórica
}

Family names in Portugal: a brief historical overview

\section{Nuno Gonçalo Monteiro}

\section{(2) OpenEdition}

\section{Journals}

\section{Edição electrónica}

URL: https://journals.openedition.org/etnografica/1599

DOI: 10.4000/etnografica.1599

ISSN: 2182-2891

\section{Editora}

Centro em Rede de Investigação em Antropologia

\section{Edição impressa}

Data de publição: 1 maio 2008

Paginação: 45-58

ISSN: 0873-6561

\section{Refêrencia eletrónica}

Nuno Gonçalo Monteiro, «Os nomes de família em Portugal: uma breve perspectiva histórica»,

Etnográfica [Online], vol. 12 (1) | 2008, posto online no dia 19 junho 2012, consultado o 10 fevereiro 2022. URL: http://journals.openedition.org/etnografica/1599; DOI: https://doi.org/10.4000/ etnografica.1599

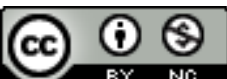

Etnográfica is licensed under a Creative Commons Attribution-NonCommercial 4.0 International License. 


\title{
Os nomes de família em Portugal: uma breve perspectiva histórica
}

\section{Nuno Gonçalo Monteiro}

\begin{abstract}
Este ensaio é uma primeira tentativa de estudar um tema que, apesar da sua enorme importância, tem recebido pouca atenção histórica: a evolução das práticas antroponímicas portuguesas; práticas essas cujo impacto se fez sentir em boa parte dos espaços tocados pela presença imperial portuguesa. $\mathrm{O}$ autor contrasta as alterações na antroponímia portuguesa que ocorreram durante a viragem do século XX com as práticas vigentes entre a aristocracia portuguesa desde as grandes mudanças que acompanharam o fim da Idade Média
\end{abstract}

PALAVRAS-CHAVE: antroponímia portuguesa, elites, casa, família.

\section{INTRODUÇÃO}

O tema proposto coloca os desafios característicos dos assuntos que parecem ser, num primeiro relance, bem conhecidos de todos mas que, uma vez analisados com maior ponderação, se revelam uma fonte de surpresas, para as quais nem sempre é possível encontrar uma resposta concludente. Por isso, esta intervenção tem objectivos modestos: ao invés de procurar esboçar uma reflexão sistemática sobre a matéria em análise, pretende apenas apresentar algumas constatações históricas gerais, cujo conhecimento parece estar longe de constituir uma evidência generalizada. Limitar-se-á a exposição, portanto, à colocação de certas questões e ao delinear de alguns tópicos, parte dos quais serão mais desenvolvidos do que outros. Procurar-se-á, assim, identificar o que seriam as práticas tradicionais portuguesas, cujo impacto se fez sentir em boa parte dos espaços tocados pela presença imperial portuguesa, para depois se inventariarem as transformações sofridas em períodos mais recentes.

O primeiro tema que importa sublinhar é que as regras legalmente estabelecidas de constituição dos nomes em Portugal que vigoraram durante a maior parte do século passado, designadamente no que aos apelidos se reporta, têm 
menos de 70 anos, pois datam do Código do Registo Civil de 10 de Abril de 1928. Como se verá, no Antigo Regime (antes de 1834) quase não existiam normas legais sobre o assunto, e o primeiro Código Civil Português, de 1867, ${ }^{1}$ nada estipulava sobre essas questões, tal como a ulterior legislação da Monarquia Constitucional sobre a matéria. O primeiro Código do Registo Civil da República, de 18 de Fevereiro de 1911, limitava-se a esclarecer que "nos assentos de nascimento não poderão figurar, em caso algum, os sobrenomes e quaisquer referências honoríficas ou nobiliárquicas do registado, nem títulos ou honras" (art. ${ }^{\circ}$ 144). Porém, o art. ${ }^{\circ} 213$ do Código do Registo Civil de 1928 continha uma adenda na qual se determinava que "o número de apelidos não deverá ser superior a quatro e serão escolhidos de entre os nomes de família dos pais dos registados, devendo os últimos ou último ser do pai".

Em 1928 vivia-se em Portugal em ditadura militar que, na sequência do golpe de Estado de 1926, pusera fim à $1 .{ }^{a}$ República, proclamada em 1910. Uma das marcas da situação era a coexistência no interior da elite política de indivíduos com as mais diversas trajectórias políticas (republicanos, monárquicos, católicos, entre outros). Era então ministro da Justiça um dos lentes de direito que ingressara no governo da ditadura militar - e aí permanecera depois da saída de António de Oliveira Salazar -, Manuel Rodrigues Júnior, tido por republicano conservador e de duvidoso catolicismo (nesse mesmo ano atacou o Centro Católico, partido ao qual pertencera Salazar). Manterse-ia como ministro da Justiça até 1940. Permanecia, portanto, nessa pasta quando, já com o lente de Santa Comba Dão de regresso ao governo, foi publicado o Código do Registo Civil de 22 de Dezembro de 1932. No anexo ao art. ${ }^{\circ} 242$ deste, retomava-se, com uma única alteração, o disposto no antes citado código de 1928: “o número de apelidos não deverá ser superior a três e serão escolhidos de entre os nomes de família dos pais dos registados, devendo os últimos ou último ser do pai". Alteração digna de monta, permitiam-se agora (art. ${ }^{\circ} 211$ ) "as referências honoríficas e nobiliárquicas, devendo o título ser sempre precedido do nome civil do registado". Nos mesmos códigos de 1928 e de 1932 se estabeleciam regras para os nomes próprios, limitados a dois "de entre os que se encontram nos diferentes calendários ou de entre os que usaram as personagens conhecidas da história", não se devendo confundir com nomes de família, "nem de coisas, qualidades ou animais".

O que importa salientar é que as regras estipuladas em 1928 alteravam radicalmente aquela que era até ao século XIX a prática hegemónica na sociedade

l O Código Civil de 1867 limitava-se a estipular, para os vários actos abrangidos pelo registo civil, a necessidade de se mencionarem "os nomes, apelidos, estado, profissão, naturalidade e residência" dos naciturnos, nubentes, falecidos ou legitimados, bem como, quando era o caso, dos seus "pais, mães, avôs e avós" (Código Civil, 1890, livro II, título I, pp. 487 e segs.), sem estabelecer nenhum tipo de relação entre uns e outros.

2 Agradeço à Dr. ${ }^{\text {a }}$ Rita Carvalho o auxílio fornecido na pesquisa destas referências. 
portuguesa e que, ainda no início do século XX, constituía um padrão frequente, pelo menos entre grupos de elite. Num livro publicado exactamente no mesmo ano em que saiu a lei, afirmava o filólogo Leite de Vasconcellos: “actualmente há muita liberdade na escolha do apelido: cada pessoa toma, por assim dizer, o apelido que lhe parece, de que gosta, ou que lhe convém. Não era assim antigamente" (Vasconcellos 1928: 327). E citava, para confirmar o que dizia, um título das Ordenações do Reino, acerca da usurpação de apelidos que não provinham da família, embora no mesmo livro dê muitos exemplos em sentido contrário. Mais adiante, acrescentava: "na junção de apelidos não existe ordem rigorosa, contrariamente ao que acontece em Hespanha (...) nós agregamos apelidos paterno e maternos, mas ao acaso" (Vasconcellos 1928: 331).

$\mathrm{Na}$ verdade, não vigorando em Portugal quaisquer normas legais sobre o assunto, o apelido ou conjugação de apelidos mais importantes eram em regra, até ao século XIX, os primeiros que se usavam depois do nome próprio, deixando-se frequentemente cair os restantes. O primeiro apelido era geralmente o paterno, embora se pudessem escolher livremente de entre os usados pelos pais ou pelos quatro avós, sendo frequentes os casos de irmãos que não usavam o mesmo apelido, como adiante se verá. Em síntese, as práticas dominantes em Portugal eram, até então, genericamente semelhantes às que se usavam no resto da Península Ibérica, ao contrário do que é usual pensar-se. ${ }^{3}$ Um exemplo paradigmático é o do próprio António de Oliveira Salazar (1889/1970), filho de António de Oliveira (1839/1932) e de Maria do Resgate Salazar (1845/1926).

É certo que os comportamentos já tinham começado a mudar no século XIX. Há toda uma pesquisa a fazer sobre o assunto, pelo que aqui apenas se apresenta um primeiro esboço. Também parece datar do século XIX o costume de as mulheres adoptarem o apelido do marido, o que, ao contrário do que afirmou Leite de Vasconcellos, ${ }^{4}$ não tinha antes expressão significativa, embora se pudesse verificar. A primeira disposição legislativa que contempla essa possibilidade é, curiosamente, a lei republicana da família de 25 de Dezembro de $1910 \ldots$

Ao que parece, a primeira legislação do Estado espanhol sobre o assunto seria uma Lei do Registo Civil de 17 de Junho de 1870, que indicava, embora de forma não impositiva e admitindo a troca dessa ordem, que o primeiro apelido seria o do pai e o segundo o da mãe. ${ }^{5}$ Em Portugal, não só se legislou sobre o assunto muito mais tarde, como em sentido diametralmente oposto. Não é fácil explicar porquê e não o vou fazer aqui. Importa sublinhar que o genealogista António Machado de Faria, que publicou em 1951, na revista

3 Cf., a título de exemplo, http://cllv.blogs.sapo.pt/29360.html

4 Vasconcellos (1928).

5 De acordo com Shiba (1996. 219). 
dos jesuítas Brotéria, um excelente artigo sobre "O uso dos apelidos em Portugal”, imputava a indesejáveis "causas estrangeiras" (embora não diga de onde...) o uso dos apelidos paternos em último lugar, bem como a adopção pelas mulheres dos apelidos dos maridos. Refere ainda que "a lei (de 1932) não foi acatada serena e complacentemente. Em vários jornais apareceram muitos protestos contra ela e outros subiram directamente até ao ministro seu autor, protestos agravados, entre os quais se encontravam membros da governação pública" (Faria 1951: 17), acrescentando que "a campanha contra a disposição do Código do Registo Civil que estabeleceu regras obrigatórias para a formação dos nomes individuais continua" (Faria 1951: 23, n. ${ }^{\circ}$ 2). Na verdade, sublinhando "ser o uso do apelido ou apelidos paternos em último lugar contrário aos costume português, principiado a pôr de parte no século passado" (Faria 1951: 18), conferia grande relevância a esses protestos, citando para o efeito vários escritos, entre os quais um publicado na Madeira, no qual se declarava: “urge (...) voltar ao sistema usado até 1932, em especial no que respeita à liberdade de cada um compor o seu nome ou o dos seus filhos, conforme lhe aprouver, entendendo-se que o fará com os apelidos usados pela família, e sem necessidade de os ordenar por esta ou aquela forma" (cit. Faria 1951: 23, n. ${ }^{\circ}$ 2).

Entretanto, se as explicações para a actual disparidade peninsular merecem uma inquirição mais aprofundada, importa reter que as soluções legalmente consagradas na Península Ibérica não deixam, por isso, de partilhar dimensões essenciais comuns. Embora destacando o apelido ou sobrenome paterno como referência principal (vindo ele logo a seguir ao nome próprio, ou como último apelido), não se esquecem, apesar de tudo, de incluir como norma o apelido da mãe enquanto parte constitutiva do nome de cada um. Ora, essa prática, legalmente consagrada, diverge claramente da seguida em outros países europeus, como a França e a Inglaterra, onde apenas se usa o apelido paterno. Como foi recentemente sublinhado, "do lado ibérico dos Pirenéus, veio a vingar um sistema onomástico em que a relação entre nome próprio e sobrenome é muito diferente da que é presumida como ponto assente nas discussões sobre onomástica dos nossos colegas anglo-franceses"; com efeito, "há diferenças muito importantes entre o mundo francês e o mundo ibérico, incluindo, está claro, os sistemas pós-ibéricos como o Brasil. A mais significativa destas diferenças é a ênfase na bilateralidade na herança dos sobrenomes entre os ibéricos" (Pina Cabral e Viegas 2007: 23 e 31)

\section{O SISTEMA TRADICIONAL NAS ELITES}

A segunda questão geral a salientar diz respeito às características do sistema que vigorava antes das recentes mutações. Para as elites aristocráticas o tema está bem estudado e pode ser sistematizado de forma clara. 
Numa muito breve e sintética resenha histórica sobre a matéria, importa destacar que, desde pelo menos a segunda metade do século XII, a nobreza medieval portuguesa adoptara um sistema tendencialmente linhagístico, com a sequente prevalência dos vínculos agnáticos sobre os cognáticos, mas sem que estes deixassem de fazer sentir a sua presença. As distintas linhagens definiamse, assim, pela sua descendência de um antepassado comum, geralmente por linhas varonis, estando esse elo associado à fixação de um nome de família, frequentemente de origem geográfica (toponímica), mas também em muitos casos com raiz em patronímicos ou, em outros, tendo por base alcunhas do fundador ou fundadores da linhagem. Embora de forma tardia, as linhagens portuguesas tiveram a sua específica tradução heráldica, em regra no século XIII ou mais tarde (Mattoso 1982; Sousa 2000: 241 e segs., e 276-283), passando o apelido de cada linhagem a estar associado a um específico brasão de armas. Em compensação, os livros de linhagens portugueses são reputados os melhores e mais detalhados da Península (Mattoso 1982). De qualquer forma, como se destacou, o peso das dimensões cognáticas, muitas vezes considerado como herança germânica (Shiba 1996: 218) nunca desapareceu completamente, nem na transmissão dos apelidos, nem do património, sendo a via usual na falta de descendência masculina.

Os finais da Idade Média conheceram, para além da famosa Lei Mental (1438), uma grande renovação nas linhagens fidalgas, de algum modo fixadas nos brasões da conhecida sala do palácio de Sintra no início do século XVI (Freire 1973). Num quadro de herança igualitária entre irmãos, que era o da legislação geral, a difusão do morgadio de origem castelhana ao longo daquele século dotou os grupos fidalgos de um novo e rígido instrumento de transmissão do património (Monteiro 2000). No entanto, nesse mundo aparentemente muito cristalizado de casas, as dimensões bilaterais nunca desapareceram. Podemos constatá-lo em relação às casas principais do reino entre finais do século XVI e inícios do século XIX.

Praticamente a única disposição legal sobre o assunto eram as Ordenações do Reino de Portugal, nas quais se recolhiam, desde o século XV, as providências legislativas de sucessivos reinados. Na sua última compilação de 1603 (Filipinas), que vigorou com ulterior legislação até ao século XIX tanto em Portugal como no Brasil, o assunto era aflorado, concretamente no título 92 do livro 5, intitulado "Dos que tomam insígnias de armas, e dom, ou apelidos, que lhes não pertencem". Aí se estipulava, de permeio com muitas outras disposições, que se podiam tomar as armas do pai ou da mãe "e se quiserem tomar somente [estremes] as armas da parte de suas mães, podê-lo-ão fazer”, admitindo-se também que alguém fosse chefe de mais do que uma linhagem, o que pressupunha que, pelo menos de uma delas, o fosse por via feminina. Destes postulados os juristas retiravam conclusões inequívocas, com ampla tradução na prática das instituições. Desde logo, quanto à transmissão da nobreza e da 
fidalguia: "Das quais Ordenações se colhe, que assim pela via das mães, como pela dos pais, se comunica a nobreza aos filhos, e podem usar dos apelidos, e armas de uma, e outra parte livremente" ${ }^{6} \mathrm{O}$ mesmo princípio era adoptado nas provas de nobreza ou de fidalguia exigidas para as habilitações, por exemplo, para se aceder ao grau de cavaleiro das ordens militares, que incidiam sobre os quatro costados. Naturalmente, esta realidade não deixava de chocar quem vinha de países onde a nobreza e os nomes de família se transmitiam apenas por via masculina. Não admira, por conseguinte, que num relatório diplomático francês de 1684 se observasse com surpresa que os fidalgos portugueses "prennent souvent les noms de leurs mères quand elles sont les meilleurs".? $\mathrm{E}$, poucos anos volvidos (1701), regista-se num escrito inglês que se reporta à população portuguesa em geral: "quando casa, a mulher não toma o nome do marido, antes neste particular existe uma grande liberdade para que as pessoas tomem os nomes que lhes agradarem e, por vezes, dois irmãos do mesmo pai e mãe têm apelidos diferentes". ${ }^{8}$

Evidentemente, os vectores mais estáveis do sistema de parentesco da nobreza e dos mecanismos de transmissão dos seus bens combinavam, desde há muito, elementos patrilineares e elementos bilaterais, como se disse. A Lei Mental no século XV (que se aplicava somente a bens doados pela coroa a membros da nobreza) e a instituição vincular (morgadio), só generalizada verdadeiramente a partir do início do século XVI, contribuíram para reforçar os princípios da primogenitura e da varonia. Mas a verdade é que a forma regular de sucessão nos morgados consagrava o chamado direito de representação (ou seja, dava preferência às netas filhas dos primogénitos sobre os tios secundogénitos), sendo excepcionais os morgados de masculinidade estrita. Apesar da importância conferida à varonia, a "qualidade" e também os "defeitos" do sangue transmitiam-se tanto pelo pai como pela mãe, com grandes implicações na política matrimonial.

No que respeita aos sucessores de casa, estes usavam quase sem excepção o mesmo apelido ou conjugação de apelidos, que aliás podiam ou não ser os da varonia. Isso resultava não apenas do facto de os títulos com grandeza estarem associados a um apelido e linhagem aos quais tinham sido concedidos, mas sobretudo da circunstância de as casas administrarem morgados cujos instituidores assim o impunham. Como as casas foram juntando morgados e houve uma lei pombalina que permitiu explicitamente essas uniões (1769), os apelidos foram sempre crescendo, com maior incidência ao longo do século XVIII, sendo o apelido primacial o primeiro ou a combinação de primeiros que

6 António de Vilas Boas e Sampaio, Nobiliarchia Portugueza. Tratado da Nobreza Hereditaria e Política (1. ${ }^{\mathrm{a}}$ ed. 1676), 3. ${ }^{\mathrm{a}}$ ed., Lisboa, 1725, p. 30.

7 Joaquim Veríssimo Serrão (ed.), Uma Relação do Reino de Portugal em 1684, Coimbra, 1960, p. 78.

8 Tomas Cox e Cox Marco, Relação do Reino de Portugal, 1701 (coord. de Maria Leonor Machado de Sousa). Lisboa, Biblioteca Nacional, 2007, p. 280. 
se usavam depois do nome próprio. Quanto a este, a tendência era para que se tomasse o nome do avô paterno, alternando-se em sucessivas gerações dois nomes próprios - o que, de resto, também a casa real de Bragança procurou fazer -, orientação que, ao fim de algum tempo, acabava por não ser possível na maior parte dos casos. A regra em situações de sucessão feminina era procurar um tio para a casar. Porém, quando isso não era possível, procurava-se um filho segundo sem casa própria, adoptando na geração seguinte, quase sem excepção, o sucessor os apelidos da casa da mãe, da qual vinha a ser senhor.

Como se disse, os apelidos compostos estavam, na primeira nobreza, quase sempre associados à instituição de morgados, e eram por isso usados pelo menos pelos sucessores das casas. Os Condes de Assumar e Marqueses de Alorna, por exemplo, passaram a assinar quase sempre, pelo menos no século XVIII, o apelido composto "de Almeida Portugal", que lhes vinha do casamento na viragem de quinhentos para seiscentos de D. Lopo de Almeida, sucessor no morgado instituído pelos seus pais em 1585, com D. Joana de Portugal, sucessora num morgado instituído por seu avô (Monteiro 2003: 344-345).

Quanto aos apelidos tomados pelas filhas e filhos não sucessores, temos um bom indicador para os 1405 filhos de 302 membros da nobreza titular que administraram as suas casas, se casaram e tiveram pelo menos dois filhos legítimos que atingiram os vinte anos de idade ou "tomaram estado" dentro do intervalo cronológico compreendido entre 1600 e 1830. A análise reporta-se a um grupo restrito de cerca de meia centena de casas que constituíam o topo indiscutível da hierarquia nobiliárquica da época. O que se observa é muito claro e bastante interessante. No século XVII, em quase todos os casamentos dos quais nasceram dois ou mais filhos, estes usavam apelidos diferentes. A percentagem é de $83 \%$. Pelo menos as filhas usavam apelidos diferente dos filhos, quase invariavelmente. Iam buscá-los à mãe, a uma avó... não havia regra fixa para o efeito. No século XVIII, porém, regista-se uma viragem em sentido inverso que se prolonga no século XIX. A percentagem de irmãos com o mesmo primeiro apelido ou conjugação de primeiros apelidos aumenta para $88 \%$. Ou seja, há uma inclinação muito clara para cada casa ficar associada a uma conjugação de sobrenomes específica, a qual era adoptada por todos quantos nela nasciam e não apenas pelo sucessor. Em todo o caso, os primeiros sobrenomes que se usavam eram os da casa, em princípio os do pai, e só depois se acrescentavam, eventualmente, os da mãe. Apesar de tudo, porém, essa tendência está longe de ser esmagadora, como se pode constatar. Por fim, importa recordar que nunca as mulheres, depois de casadas, tomavam o apelido do marido; esta era, pois, uma prática ausente na elite aristocrática portuguesa.

Em termos gerais, estas orientações serão prosseguidas pelas famílias fidalgas antigas ao longo do século XIX, quando, na sequência do triunfo liberal em 1834, se vão abolir a Lei Mental, os bens da coroa, a prazo os morgadios e, globalmente, quase todos os vectores sobre os quais repousavam os antigos modelos 
de reprodução social dos grupos aristocráticos. Os filhos não sucessores, num contexto de desagregação do sistema, passam a usar os apelidos das casas do primogénito e, algumas vezes, acrescentam o título da mesma entre parêntesis.

Quadro 1

Apelidos usados pelos filhos de titulares (1600-1830)9

A

Pais nascidos $\begin{gathered}\text { Com filhos } \\ \text { usando apelidos } \\ \text { diferentes }\end{gathered}$

Antes de 1650

$1651-1700$

$1701-1750$

pós-1750
46

49

20

10

125
B

Com todos os filhos
com os mesmos
apelidos

Total
de
titulares

Percentagem

de

A

$84 \%$

$77 \%$

$37 \%$

$12 \%$

Na verdade, o padrão de comportamento que encontramos para o reino, vamos descobri-lo na célebre genealogia das principais famílias paulistas dos séculos XVI, XVII e XVIII, reunida nos finais deste último século por Pedro Taques de Almeida Pais de Leme (1714?-1777). ${ }^{10}$ Num total de 645 casamentos com dois ou mais filhos dos quais se conhecem os sobrenomes, os que produziram para cima de 3800 descendentes legítimos, observamos que apenas em $8,2 \%$ dos casos todos os filhos partilhavam o mesmo sobrenome ou conjugação de sobrenomes. Ou seja, em quase $92 \%$ tinham conjugações de apelidos diferentes e em mais de três quartos do total não tinham sequer um apelido em comum. As elites paulistas partilhavam, assim, de forma notória, o modelo de comportamento das elites reinóis. Pode sustentar-se, assim, que, nessa matéria, os modelos portugueses foram transpostos e retomados pelas elites do Brasil colonial.

No entanto, é necessário ter em conta que, tanto nestas, como nas demais, não existia verdadeiramente um nome oficial. Até muito tarde, o nome ou nomes que se recebiam na pia baptismal e que constavam do registo paroquial de baptismo eram apenas o nome ou nomes próprios. E importa recordar que os registos paroquiais só se generalizaram após o Concílio de Trento (1545-

9 Bases de dados usadas em Monteiro (2003).

10 Pedro Taques de Almeida Pais de Leme, Nobiliarquia Paulistana Histórica e Genealógica (ed. de Afonso de E. Taunay), 3. ${ }^{\text {a }}$ ed., São Paulo, 3 tomos, 1952-1953. 
-1563), isto é, só passaram a existir na maior parte dos casos para a segunda metade do século XVI ou até mais tarde. Depois, ao longo da vida, fosse por ocasião do casamento, fosse aquando de algum registo notarial, requerimento ou habilitação, adoptavam-se certos apelidos. Mas não existia nenhum registo oficial do nome das pessoas, o qual podia ir mudando ao longo das suas vidas.

O número de apelidos ou sobrenomes era, até ao século XVIII, limitado. Mesmo entre os fidalgos destacados, podia-se usar apenas um, dois, às vezes três, raramente mais. Depois, a regra da acumulação de morgados estimulou o aumento do número dos nomes. Como as casas principais iam juntando morgados das mais diversas proveniências e os seus instituidores impunham o uso do apelido da respectiva linhagem, os administradores dos morgados (geralmente os primogénitos) foram acrescentando os apelidos correspondentes a cada um dos morgados principais que possuíam. Esta prática, como se disse, ficou reforçada quando a legislação pombalina de 1769 baniu as restrições à acumulação de morgados, de resto, nunca respeitadas na íntegra. Em finais do século XVIII era normal que um primogénito e senhor de casa acumulasse uma apreciável quantidade de apelidos, ao contrário daquilo que era anteriormente a prática corrente.

\section{Quadro 2}

Casamentos com dois ou mais filhos nas famílias de S. Paulo

Têm todos o mesmo apelido ou conjugação de apelidos

53

$8,2 \%$
Usam apelido ou conjugação

de apelidos diferentes com um comum a todos

96

$14,9 \%$
Não têm nenhum

apelido comum

a todos

496

$76,9 \%$

\section{OS MODELOS POPULARES}

Sobre esta questão, limitar-me-ei a um breve enunciar de problemas, até porque irá ser desenvolvida em outro texto e as fontes possíveis são infindáveis. Não é muito o que se conhece sobre a génese e as formas de transmissão dos apelidos nos grupos, digamos, populares. Sabe-se que, no período medieval, os nomes das pessoas eram geralmente constituídos pelo nome próprio e pelo patronímico, eventualmente, por um terceiro elemento, uma alcunha, profissão ou topónimo, que servia para ultrapassar as frequentes homonimias. ${ }^{11}$ Conhece-se pouco sobre como é que estes elementos evoluíram para apelidos. E, em particular, como é que apelidos da mais selecta fidalguia, como Silva, 
totalmente ausentes da antroponímia medieval, se tornaram os mais comuns na população portuguesa. Como satirizava, em meados de Setecentos, Cavaleiro de Oliveira, "não há um único apelido em Portugal que não pertença, simultaneamente, à fidalguia mais estreme e à gentalha mais baixa", ${ }^{12} \mathrm{ou}$, tal qual se dizia num processo de casamento contra a vontade dos pais em 1784, "no Reino muitos homens obscuros adoptam apelidos de Casas, não só ilustres, mas titulares". ${ }^{13}$

Com a generalização dos registos paroquiais a partir de finais do século XVI, será possível obter uma imagem de conjunto segura, passível de inquisição em futuras investigações. Em todo o caso, o mais frequente parece ser nos registos de baptismo os nascituros aparecerem identificados apenas pelo nome próprio, mas já nos registos de casamentos e de óbitos surgirem quase sempre com um sobrenome associado ao nome próprio. O sobrenome podia ser tomado de uma alcunha (em gerações ulteriores eventualmente transformado em apelido), ter uma origem toponímica (o que parece ser frequente até muito tarde), ser constituído por um segundo nome próprio, ter uma base patronímica ou, por fim, retomar apelidos, tomados dos progenitores, dos padrinhos ou até (no caso de criados ou de escravos) do senhor.

No século XVII, algumas breves sondagens realizadas em registos paroquiais de freguesia rurais, designadamente nos registos de casamentos, sugerem, nos quatro cantos de Portugal, a inexistência de quaisquer regras dominantes que estivessem na base da adopção dos sobrenomes. Estes podiam ser o apelido do pai, ou da mãe, ou um apelido não coincidente com nenhum dos que os pais usavam. Ainda se registava a adopção de patronímicos. ${ }^{14}$

Em síntese, o que se sabe sobre as modalidades de constituição dos sobrenomes nos meios populares sugere que, também aí, se observa que, não existindo um quadro normativo que impusesse regras legais, as práticas aparentemente dominantes se caracterizavam pela diversidade. Resta, portanto, avaliar em que medida este quadro foi alterado pela evolução oitocentista.

\section{A EVOLUÇÃO OITOCENTISTA}

Embora se detectem mutações em períodos anteriores, não restam dúvidas que o século XIX foi um momento essencial de viragem. No entanto, não são

12 Cavaleiro de Oliveira, Recreação Periódica (1751) (trad. de Aquilino Ribeiro), Lisboa, Biblioteca Nacional, 1922, I, p. 216.

13 IAN/TT, Desembargo do Paço, Corte, maço n. ${ }^{\circ} 2117$, n. ${ }^{\circ} 78$.

14 Em 44 nubentes cuja paternidade se encontra identificada em Barrancos, verifica-se que 20 homens tomaram o apelido do pai, 4 o da mãe e 20 um outro, de origem desconhecida; nas mulheres, 13 retomaram-no do pai, 6 da mãe, e 25 um cuja proveniência se desconhece (Cf. João Cosme, Fontes para a História de Barrancos: Registos Paroquiais, 1674-1704. Barrancos, Câmara Municipal de Barrancos, 2001). Algo de similar se detectou em diversas sondagem efectuadas no IAN/TT, registos paroquiais. 
ainda claros quais os factores que intervieram nessa mutação, nem a cronologia da mesma.

A hipótese da qual partimos é de que a mutação oitocentista foi protagonizada sobretudo pelos grupos familiares em processo de mobilidade social ascendente, os quais, pelo que se conhece, desenvolviam já práticas de controlo do número de filhos nascidos e eram permeáveis aos valores e comportamentos que se podem associar à cultura francesa e ao código napoleónico. Um bom indicador pode ser obtido através da análise dos comportamentos dos 2554 indivíduos que, entre 1834 e 1910, passaram pelas câmaras dos deputados, dos pares e/ou dos senadores da Monarquia Constitucional portuguesa (Mónica et al. 2004-2006). Embora haja muitas lacunas de informação, designadamente quanto à filiação (quase um terço do total), trata-se em todo o caso de uma amostra muito significativa. Com efeito, só uma minoria dos parlamentares era fidalga de nascimento, sendo a esmagadora maioria recrutada precisamente entre os grupos em ascensão espalhados por todo o país. Integrando maioritariamente as elites escolarizadas, se nos ativermos apenas aos deputados, sabemos que cerca de metade pertencia ao funcionalismo (militares, magistrados e funcionários), quase um quinto a profissões liberais (médicos, advogados e jornalistas), e os restantes eram proprietários ou negociantes (Almeida 1995: 156).

A primeira observação que interessa relevar reporta-se às categorias. Na verdade, se se pretendesse esgotar as situações detectáveis na fonte, ter-se-iam de aceitar mais de três dezenas de categorias, tal a diversidade que se encontra! Houve, portanto, que reduzir o número de situações possíveis a onze, duas das quais acumuláveis.

As conclusões que constam do quadro seguinte são, globalmente, bastante significativas. Não temos filiação para um pouco mais de um quarto dos parlamentares. Naqueles cuja filiação se conhece, detecta-se, como se disse, uma grande disparidade de situações. No entanto, os parlamentares que só têm apelidos paternos são uma clara maioria, pois constituem quase $70 \%$ do total. Só uma ínfima minoria $(1,7 \%)$ usa apenas apelidos maternos. Finalmente, $27 \%$ tem apelidos do pai e da mãe, e mais de 14\% tem um ou mais apelidos que não são nem paternos nem maternos. Acresce ainda que mais de $20 \%$ dos pais têm o mesmo apelido, o que, em parte dos casos se deverá a parentesco entre os dois conjugues, mas na maioria traduzirá o facto da mãe ter adoptado o apelido do pai depois do casamento. Note-se que a regra legalmente prescrita em 1928-32 (apelidos paternos e maternos - apelido(s) do pai no fim) só é adoptada em pouco mais de 14\% dos casos. Estava longe de ser a norma, portanto.

Os indicadores apresentados traduzem claramente uma situação de transição. Mantém-se uma pluralidade de usos, e quase um terço dos parlamentares tomava, pelo menos, um apelido da mãe. Mas a tendência dominante é 
para a utilização exclusiva do apelido paterno. Ao contrário do que terá sido a evolução espanhola, onde antes mesmo de 1870 a regra dominante terá continuado a ser o uso do duplo apelido paterno e materno.

Podemos ainda obter um outro indicador significativo através de uma amostragem dos alunos que frequentaram a Escola Médico-Cirúrgica do Porto entre 1825 e 1895. A maioria dos alunos não era natural do Porto, mas sim de concelhos rurais do Centro e Norte de Portugal, traduzindo a frequência da escola um apreciável investimento familiar e inscrevendo-se, em regra, num lógica social de mobilidade ascendente. Como na maior parte dos casos não se conhece o apelido da mãe, a contabilidade só pode ser feita em relação ao do pai. Em todo o caso, a tendência dominante parece clara: mais de metade $(57,2 \%)$ dos alunos reproduzia só o apelido ou apelidos paternos, às vezes deixando cair algum, outras, quando o nome final era exactamente igual ao do pai, acrescentando Júnior. No entanto, para além de 4,2\% de filhos de pai ou pais incógnitos, detectamos $32,5 \%$ de alunos que combinam o apelido do pai com outro e ainda $6 \%$ que não usam qualquer apelido paterno. Em síntese, voltamos a encontrar indicadores globalmente próximos daqueles que antes detectámos para os deputados: uma tendência agnática dominante, mas também uma diversidade apreciável. ${ }^{15}$ Mais de um terço dos alunos continua a usar um apelido que não era utilizado pelo respectivo pai.

Como se podem interpretar os indicadores referidos? A resposta não será inequívoca. Mas pode sugerir-se que a evolução detectada parece denotar uma crescente influência de modelos europeus, principalmente franceses. De resto, essa matriz pesava fortemente sobre a legislação portuguesa em matérias de direito da família adoptadas ao longo do século XIX. Mais genericamente, os indicadores encontrados parecem poder associar-se à afirmação da modelo da "família burguesa": ${ }^{16}$ uma construção social cujos contornos históricos estão longe de se encontrar bem estudados no contexto português. Podemos supô-la como uma unidade refeita em cada geração, em função de um novo casamento. A dimensão patriarcal, a influência francesa e a adopção de parâmetros legais que reforçam a autoridade paternal parecem ser marcas deste modelo emergente, sem que as referência maternas desapareçam.

Em todo o caso, esta incursão num terreno pouco ou nada desbravado no campo historiográfico para períodos recentes coloca muitas questões que ficam sem resposta. De algum modo ficam delimitados os desafios para ulteriores investigações.

15 Luís Miguel S.L. Cravo, "Os alunos da Escola Médico-Cirúrgica do Porto no século XIX - Uma perspectiva”, Partes I e II, Genealogia \& Heráldica, n. ${ }^{\circ}$ 3, 2000, pp. 345-367 e n. ${ }^{\circ}$ 4, 2000, pp. 381-405. O trabalho referido reporta-se a 381 alunos e apenas recolhe os seus nomes de cinco em cinco anos. 16 Cf. Pina Cabral (1991). Não deixa de ser surpreendente a escassa produção historiográfica sobre este assunto. 
Quadro 3

Apelidos dos parlamentares portugueses (1834-1910)

\begin{tabular}{|c|c|c|c|}
\hline Categorias & $\begin{array}{c}\text { Número } \\
\text { de indivíduos }\end{array}$ & Percentagem & $\begin{array}{l}\text { Percentagem daqueles } \\
\text { cuja filiação se conhece }\end{array}$ \\
\hline $\begin{array}{l}\text { só tem apelidos paternos } \\
\text { - com a mesma sequência }\end{array}$ & 1008 & $40,0 \%$ & $54,8 \%$ \\
\hline $\begin{array}{l}\text { só tem apelidos paternos } \\
\text { - com distinta sequência } \\
\text { ou faltando algum }\end{array}$ & 277 & $11,0 \%$ & $15,0 \%$ \\
\hline $\begin{array}{l}\text { só tem apelidos maternos } \\
\text { - com a mesma sequência }\end{array}$ & 18 & $0,7 \%$ & $1,0 \%$ \\
\hline $\begin{array}{l}\text { só tem apelidos maternos } \\
\text { - com distinta sequência } \\
\text { ou faltando algum }\end{array}$ & 12 & $0,5 \%$ & $0,7 \%$ \\
\hline $\begin{array}{l}\text { tem apelidos paternos e maternos } \\
\text { - apelido(s) do pai no fim }\end{array}$ & 260 & $10,3 \%$ & $14,1 \%$ \\
\hline $\begin{array}{l}\text { tem apelidos paternos e maternos } \\
\text { - apelido(s) do pai no princípio }\end{array}$ & 149 & $5,9 \%$ & $8,1 \%$ \\
\hline $\begin{array}{l}\text { tem apelidos paternos e maternos } \\
\text { - com distinta sequência }\end{array}$ & 96 & $3,8 \%$ & $5,2 \%$ \\
\hline $\begin{array}{l}\text { não tem apelidos coincidentes } \\
\text { com os progenitores }\end{array}$ & 21 & $0,8 \%$ & $1,1 \%$ \\
\hline pais com apelidos coincidentes* & $(378)$ & & \\
\hline $\begin{array}{l}\text { algum apelido não coincidente } \\
\text { com os dos pais* }\end{array}$ & $(244)$ & & \\
\hline $\begin{array}{l}\text { filiação desconhecida/ } \\
\text { dados insuficientes }\end{array}$ & 681 & $27,0 \%$ & \\
\hline total de indivíduos & 2522 & $100,0 \%$ & $100,0 \%$ \\
\hline
\end{tabular}

* Categorias cumulativas com as anteriores.

\section{BIBLIOGRAFIA}

ALMEIDA, Pedro Tavares de, 1995, A Cconstrução do Estado Liberal. Elite Política e Burocracia na "Regeneração" (1851-1890), dissertação de doutoramento policopiada. Lisboa, Universidade Nova.

Código Civil, 1890, Carta de Lei de 1 de Julho de 1867, Porto.

FARIA, António Machado de, 1951, "O uso dos apelidos em Portugal”, Brotéria, vol. LII, fasc. 2 .

FREIRE, Anselmo Brancaamp, 1973, Brasões da Sala de Sintra, 2. ${ }^{\text {a }}$ ed., 3 vols., Lisboa.

GONÇALVES, Iria, 1996, "Identificação medieval: o nome dos dirigentes concelhios em finais de trezentos”, Revista Portuguesa de História, tomo XXXI, vol. 2. 
GONÇALVES, Iria, 1973, “Onomástica pessoal da Lisboa de quinhentos”, Boletim Cultural da Junta Distrital de Lisboa, n. ${ }^{\circ}$ 79-80.

— História, n. ${ }^{\circ} 5$.

—, 1971, "Amostra de antroponímica alentejana do século XV", Do Tempo e da História, n. ${ }^{\circ} 4$.

Mattoso, José, 1982, A Nobreza Medieval Portuguesa. A Família e o Poder. Lisboa, Editorial Estampa.

MÓNICA, Maria Filomena, (ed.) et al., 2004-2006, Dicionário Biográfico Parlamentar, 3 volumes. Lisboa, Imprensa de Ciências Sociais.

MONTEiro, Nuno Gonçalo, 2003, O Crepúsculo dos Grandes. A Casa e o Patrimómio da Aristocracia em Portugal (1750-1832), 2. ${ }^{\text {a }}$ ed., Lisboa, Imprensa Nacional-Casa da Moeda.

- Nuno Gonçalo, 2000, "Aristocratic succession in Portugal (16 $6^{\text {th }}-19^{\text {th }}$ centuries)", em João de Pina Cabral e Antónia Pedroso de Lima (dirs.), Elites. Choice, Leadership and Sucession. Oxford e Nova Iorque, Berg Publishers.

PINA CABRAL, João de, 1991, Os Contextos na Antropologia. Lisboa, Difel.

PINA CABRAL, João de Pina, e Susana Matos Viegas, 2007, "Nomes e ética: uma introdução ao debate", in idem (orgs.), Nomes: Género, Etnicidade e Família. Lisboa, Almedina.

SANTOS, Maria Leonor F. O. Silva, 2003, “A onomástica, o indivíduo e o grupo”, Arquipélago. História, 2. ${ }^{\text {a }}$ série, vol. 7.

SHIBA, Hiroko, 1996, "Evolución histórica del nombre civil en España. Una apoximación a su origen”, Boletin de Nagoya Women's Júnior College of Commerce, n. 36.

SOUSA, Bernardo Vasconcelos e, 2000, Os Pimentéis. Percursos de uma Linhagem da Nobreza Medieval Portuguesa (séculos XIII-XIV). Lisboa, Imprensa Nacional-Casa da Moeda.

VASCONCELLOS, J. Leite de, 1928, Antroponimia portuguesa: tratado comparativo da origem, significação, classificação, e vida do conjunto dos nomes proprios, sobrenomes... . Lisboa, Imprensa Nacional.

Family names in Portugal: a brief historical overview - Nuno Monteiro - Instituto de Ciências Sociais da Universidade de Lisboa • nuno.monteiro@ics.ul.pt

This essay constitutes a first attempt to study a theme which, in spite of its enormous importance, has received little historical attention: the evolution of the Portuguese practices of anthroponymy that had a worldwide impact due to Portuguese imperial expansion. The author contrasts the changes that occurred at the turn of the twentieth century to the practices that were prevalent among the Portuguese aristocracy ever since the great changes that took place at the end of the Middle Ages.

KEYWORDS: portuguese anthroponymy, elites, household, family. 